\title{
"NAMORIDO": UMA FORMA CONTEMPORÂNEA DE CONJUGALIDADE?
}

\author{
Juliana Puppin Duarte* \\ Maria Lúcia Rocha-Coutinho**
}

\section{Resumo}

Este estudo teve como objetivo entender o "namorido", forma de relacionamento comum entre jovens da zona sul do Rio de Janeiro. Neste relacionamento, após breve namoro, o casal decide morar junto, sem necessariamente planejar uma futura oficialização. Foram entrevistadas cinco mulheres com idades entre vinte e sete e trinta e sete anos, que trabalham fora de casa e estão envolvidas, há pelo menos um ano, em um relacionamento amoroso a que estamos denominando "namorido". As entrevistas foram semidirigidas, gravadas em áudio, transcritas na íntegra e os textos resultantes submetidos a uma análise de discurso. Os resultados apontam para o fato de que o "namorido" parece ser uma modalidade de relacionamento resultante do individualismo exacerbado das sociedades contemporâneas em que os vínculos afetivos são mais fluidos e maleáveis. Nele, os indivíduos buscam uma satisfação pessoal instantânea nos relacionamentos amorosos, dispensando, assim, um tempo maior para o conhecimento mútuo. Além disso, não se faz necessário que o casal participe, dê satisfaçóes ou mesmo conheça os familiares do/a parceiro/a e não há compromisso com a durabilidade, nem com a geração de descendentes.

Apesar disso, em muitos aspectos o "namorido" se assemelha aos casamentos contemporâneos e, para as pessoas envolvidas neste tipo de relação, o fato de ela não ser oficializada não faz com que a união entre os cônjuges seja menos comprometida.

Palavras-chave: "namorido"; individualismo; conjugalidade.

* Mestre em Psicologia Social - UNIVERSO, Doutoranda do Programa EICOS/UFRJ.

** Professora Titular - Mestrado em Psicologia - UNIVERSO. Professora Associada - Programa EICOS - UFRJ. 


\begin{abstract}
"NAMORIDO": A CONTEMPORARY TYPE OF CONJUGAL RELATIONSHIP?

This study aimed at better understanding the "namorido", a common type of relationship among young people who live in the south area of the city of Rio de Janeiro, Brazil, in which, after dating during a briefperiod, a couple decides to live together, without necessarily intending to make it official in the future. We interviewed five women, aged 27 to 37, who work and are involved for at least one year in a "namorido" type of relationship. The interviews were semistructured, tape-recorded and fully transcribed and the resulting texts submitted to a discourse analysis. The results point to the fact that the "namorido" seems to be a type of relationship that results from the individualism typical of our contemporary societies in which the affective bonds are more fluid and flexible. In this type of relationship, individuals seek instantaneous, thus dismissing a longer period of mutual knowledge. Besides, it is not necessary that the couple communicates or even meet his/her partner's family members and there is no compromise with the relationship's durability or procreation. Despite that, in many aspects, the "namorido" is similar to contemporary marriages e for the people involved in this kind of relationship, the fact that it is not made official does not mean that the partners are less compromised with it.

Keywords: "namorido"; individualism; conjugality.
\end{abstract}

\title{
INTRODUÇÃo
}

Em toda sociedade sempre coexistiram vários modelos de conjugalidade, ainda que um deles possa ter se tornado dominante para um determinado grupo cultural em um momento histórico específico. Assim, pode-se dizer que o relacionamento entre duas pessoas pode envolver diferentes tipos de arranjo, como o casamento por interesse, o casamento por amor, a coabitaçáo não oficializada, o relacionamento com alguém já comprometido e, mais recentemente, o relacionamento entre pessoas do mesmo sexo. Pode-se dizer, contudo, que, desde a grande difusão do Cristianismo, o matrimônio oficializado passou a ser não apenas a forma mais aceita e difundida de uniáo entre um homem e uma mulher como também constituiu um espaço privilegiado para a concretização de interesses maiores, como a construção e manutenção da família nos moldes historicamente para ela estabelecidos, visando, geralmente, servir aos interesses econômicos e políticos das famílias mais abastadas e do Estado.

Tradicionalmente, o casamento oficial - e faz-se necessário observar que estamos nos referindo aqui às formas de união dos grupos dominantes, uma vez que os casamentos entre camponeses, servos ou escravos nunca demandaram atenção por parte de nenhuma instituição de poder, tendo em vista que nestes não há interesses a defender - sempre foi balizado por direitos e obrigaçóes que 
deveriam ser seguidos por ambos os membros do casal. Mesmo com o passar dos séculos, mantém ainda algumas de suas características primeiras, como: constituir o espaço da sexualidade lícita que objetiva a procriação de filhos legítimos. Uma vez que o casamento oficializado no civil - e, na maioria das vezes, também no religioso - praticamente reinou absoluto durante vários séculos, faremos muitas vezes menção a esse modelo de relacionamento. Este servirá, inclusive, de base de comparação com o que talvez possa ser considerada uma nova forma de conjugalidade, a qual estamos denominando de "namorido"1.

Por vários séculos, os sentimentos de homens e mulheres não foram levados em conta para que as uniôes ocorressem. Tal fato não significava, contudo, a proibição de casamentos realizados por afeto ou afinidade, mas, antes, eram outros os ganhos esperados de um enlace matrimonial. Às vezes, a ligação emocional entre o casal emergia após a união, mas essa não era uma questão essencial. Assim, ainda que alguns matrimônios se realizassem por afinidade, o amor náo era desencadeador de uma união na época. Este só começa a entrar em cena nas cantigas dos trovadores, no fim do século XI. Segundo Del Priore (2006), deu-se, entâo, o surgimento do amor cortês, sentimento que se situava mais no plano da idealização do que no da prática efetiva. Sua dificuldade de concretização era exatamente o elemento que o alimentava, tornando-o "táo mais ardente quanto impossível" (Del Priore, 2006: 70).

Segundo Giddens (1993), o amor como paixão ardente era, de fato, na grande maioria das vezes, vivenciado apenas fora da união conjugal, por ser considerado perigoso. Isto porque esse tipo de amor impunha urgência, apresentava-se muito forte, levava os sujeitos a se comportarem como se estivessem sob o efeito de um encantamento, o que fazia com que as obrigaçóes rotineiras fossem postas de lado. $\mathrm{O}$ amor não estava relacionado ao sexo e, como o coito conjugal servia à procriação, sua prática não exigia intimidade ou desejo. Assim, aos cônjuges se reservava a sexualidade casta, enquanto que o prazer pertencia às relaçóes fora do matrimônio.

Foi somente no final do século XVIII que o amor romântico entrou em cena de forma mais marcante. Ele constituía, na verdade, um protesto contra a moral vigente e uma valorizaçáo das emoçóes. Segundo Giddens (1993), o amor romântico trouxe liberdade para se escolher o pretendente, responsabilizando a pessoa por sua escolha e, consequentemente, por sua felicidade. Como a dissoluçáo dos laços conjugais era praticamente impossível, o pretendente tinha que ser especial para valer a pena uma existência inteira a seu lado. Contudo, apesar da possibilidade de livre escolha do futuro marido, durante o final do século XIX e início do século XX ainda havia jovens que descartavam pretendentes que não agradavam à sua família. 
Assim, na prática, a livre escolha do cônjuge náo aconteceu de imediato, mas, ao contrário, a realidade foi mudando aos poucos. Durante um bom tempo, o ideal seria tentar unir o útil ao agradável, isto é, encontrar um(a) noivo(a) com quem houvesse alguma afinidade e que também favorecesse os interesses familiares.

No Brasil, com o passar dos séculos, os relacionamentos foram sofrendo alterações significativas, acompanhando as tendências ditadas pelas sociedades europeias, posteriormente acrescidas daquelas que vigoravam na América do Norte. No início de nossa colonização, os relacionamentos afetivos se davam entre os colonizadores portugueses e as índias e, mais tarde, também com as escravas africanas que aqui chegaram, tendo em vista que apenas os homens vinham para o Brasil. Somente quando os portugueses começaram a se fixar na nova terra e, em parte, por pressão dos jesuítas, contrários às relaçôes sexuais fora do casamento, é que as mulheres europeias começaram a desembarcar por aqui, formando as primeira famílias "oficiais”, a que Freyre (1951) denominou família de organização patriarcal.

Nas classes mais altas, como acontecia nas sociedades europeias da época, este tipo de casamento tinha finalidades bem claras e específicas: manter ou aumentar a riqueza das famílias, bem como conservar alianças de ordem política, social ou econômica. Assim, eles se realizavam segundo o desejo do patriarca, ou do responsável pela família, sempre visando algum benefício social, político ou econômico. Aos filhos restava apenas a obediência. O dote era um item fundamental para a concretização do enlace, que podia se dar a partir do momento em que a moça completasse 12 anos e os "varôes", 14 anos de idade. Grandes diferenças etárias entre os cônjuges eram aceitas com naturalidade, assim como casamentos entre parentes, o que contribuía, inclusive, para a preservação do patrimônio familiar.

O casamento no Brasil se manteve praticamente o mesmo até a segunda metade do século XIX, quando, com a chegada da corte portuguesa ao Brasil, ganharam força as ideias dos médicos higienistas, que muito contribuíram para alterar as relaçôes familiares no país (Costa, 1989). Como era alta a taxa de mortalidade infantil, as atençôes desses médicos voltaram-se para o desenvolvimento saudável da criança, cuja saúde, segundo eles, dependia, em grande parte, da saúde de seus pais. Assim, os higienistas criticaram e combateram vários aspectos do casamento colonial, visando o bem-estar do casal e dos filhos, inserindo, aos poucos, o amor nos relacionamentos conjugais.

O período que vai do fim do século XIX até meados do século XX foi marcado por um processo de modernização da sociedade brasileira que, aos poucos, acabou por afetar os relacionamentos afetivos. Neste novo tempo, além do amor e do companheirismo, a satisfação sexual também passou a ser vista como saudável para ambos os cônjuges. A antiga união por interesse (Mello, 1997) passou a ser

Psic. Clin., Rio de JANeiro, vol.23, N.2, P.II7 - I35, $201 \mathrm{I}$ 
considerada vergonhosa e o amor foi valorizado, visando o que deveria ser o grande projeto de homens e mulheres no casamento: a criação dos filhos.

A entrada no século XX marca, desta forma, um declínio do poder familiar no controle da vida dos indivíduos. A partir de então, as relaçóes passaram a não se fundamentar mais na transmissão do patrimônio. Paralelamente ao declínio do poder patriarcal, ocorre um aumento crescente do individualismo que, gradativamente, vai permitindo que os sujeitos se tornem mais autônomos e senhores de seus desejos e realizaçóes. Ou seja, pouco a pouco, seguindo os passos dos países europeus e norte-americanos, o namoro no Brasil vai mudando, a sexualidade vai ficando mais igualitária e o amor também vai se transformando para se adaptar aos novos tempos.

As formas atuais de relação amorosa acabaram por igualar os enamorados, permitindo uma união de troca e intimidade, constituindo o que Giddens (1993) denominou amor confluente. Neste tipo de amor, ambos os parceiros estáo abertos ao outro, expressam seus sentimentos e trabalham juntos no desenvolvimento da intimidade. Trata-se de um amor mais igualitário, em que ambos os cônjuges devem investir na relação para dela retirar satisfação. A sexualidade é negociável, isto é, não precisa ser necessariamente monogâmica ou heterossexual e o sexo deve proporcionar prazer e satisfação para ambos os parceiros. Assim, nos relacionamentos contemporâneos, ou, para empregar a expressão de Giddens (1993), na relação pura, o compromisso é com a satisfação extraída do próprio relacionamento, a escolha do companheiro é voluntária, há proximidade, confiança e satisfação recíproca.

Neste tipo de relacionamento, o envolvimento afetivo termina quando um dos parceiros não está mais satisfeito ou motivado. Entretanto, para haver compromisso e estabilidade numa relaçáo amorosa, faz-se necessário ter alguma garantia de que a relaçáo se manterá por certo período de tempo, a fim de que o relacionamento seja consolidado. Numa sociedade instável, a segurança do relacionamento está vinculada ao compromisso pessoal com a relaçáo. Se antes havia garantias e motivos externos para a duração de um relacionamento, atualmente é o compromisso entre os parceiros o grande mantenedor da união. Além disso, o compromisso entre eles fornece apoio emocional para suportar as possíveis dificuldades que possam vir a surgir no relacionamento. Para Giddens (2002: 89), uma relaçáo que existe apenas pela satisfação que traz é facilmente ameaçada por tensôes que refletem as "dificuldades inerentes na criação ou na sustentação de uma relação em que há equilíbrio e reciprocidade entre o que cada um traz para a relação e o que deriva dela".

Segundo Bauman (2004), há uma contradição nos relacionamentos atuais, pois, ao mesmo tempo que se anseia por um envolvimento mais íntimo, mais comprometido, este náo é seguro, tendo em vista que pode ser rompido a qualquer 
momento. Isto decorre do fato de a sociedade contemporânea ser marcada pela fluidez e transitoriedade de todos os tipos de vínculo, sejam eles econômicos ou afetivos. Bauman (2004) assinala que a descrição do relacionamento puro de Giddens (1993) é bem familiar para os jovens nascidos na virada do século XX para o XXI. Diferentemente de Giddens (1993), contudo, Bauman (2004) acredita que as pessoas hoje veem as relaçóes afetivas como investimentos financeiros e o compromisso como uma armadilha a ser evitada.

O autor compara, assim, os amantes a investidores financeiros, uma vez que as pessoas aplicam tempo, dinheiro e dedicaçáo esperando que seus esforços sejam recompensados. O lucro esperado do investimento amoroso, segundo ele, é a segurança; a certeza de que se terá companhia, apoio, consolo, alguém para aliviar a solidão e para aplacar a insegurança diante da velocidade das mudanças, já que tudo é transitório. Tratar os relacionamentos como investimentos não reduz, contudo, a insegurança, pois, no mundo dos negócios, não há espaço para juras de amor eterno e o/a parceiro/a pode querer trocar de investimento a qualquer momento. Na contemporaneidade, tudo é efêmero - o desejo, os estímulos, os bens de consumo - e, assim, as mudanças ocorrem muito rapidamente. O que hoje é tecnologia de ponta amanhã pode já estar ultrapassado, superado por uma nova invenção. Esse mesmo tipo de padrão, segundo Bauman (2004), pode ser percebido nos envolvimentos amorosos.

O casamento contemporâneo no Brasil absorveu muitas características dos relacionamentos puros, deixando para trás a rigidez dos antigos papéis de gênero. Questóes como intimidade, compromisso e sexualidade satisfatória foram a ele incorporadas. Como aponta Badinter (1986: 201), o casamento era "sinônimo de segurança, respeitabilidade e de fecundidade. Hoje perdeu essas 3 características essenciais". As relaçôes duradouras não são mais uma certeza, muito menos os filhos. O surgimento de métodos contraceptivos mais eficazes, como a pílula anticoncepcional, deu às mulheres maior controle sobre sua sexualidade, permitindo a diminuição do número de filhos, o planejamento dos mesmos e até a opção por não ter filhos. Assim, a relação sexual deixa de ter um compromisso exclusivo com a sucessão das gerações. O importante agora é a qualidade das relaçôes para os indivíduos nela envolvidos, sejam eles homens ou mulheres. A "nova" sexualidade, a que Giddens (1993) denominou sexualidade plástica, permite a realização pessoal através do reconhecimento das preferências individuais e das tolerâncias sexuais dos parceiros e é também uma forma de se expressar a intimidade.

No que diz respeito à divisão de papéis entre homens e mulheres, parece que ela ainda está mais igualitária no plano do discurso do que no da prática. Como aponta Jablonski (2007: 213), "os casais parecem vivenciar um conflito 
entre as propostas igualitárias modernas e as práticas hierárquicas tradicionais". Nas pesquisas realizadas pelo autor, os homens se consideraram participativos nas tarefas dentro do lar. Contudo, na prática, a participação masculina parece ser mais uma ajuda do que uma real divisão de tarefas. Essa falsa simetria gera conflitos na relaçáo, principalmente em uma sociedade em que a satisfação pessoal é cada vez mais estimulada e valorizada para ambos os sexos.

A segurança trazida pela antiga garantia de longevidade dos relacionamentos também desapareceu no casamento tradicional ${ }^{2}$. Até a segunda metade do século $\mathrm{XX}$, independente de sua qualidade, o matrimônio era indissolúvel. Praticamente só a morte dissolvia o laço conjugal. Contudo, como a expectativa de vida era baixa, ficar casado por toda a vida não constituía um período tão longo como hoje. $\mathrm{Na}$ contemporaneidade, como aponta Jablonski (1991), as juras de amor eterno nos relacionamentos amorosos foram substituídas pelo "até que a vida nos separe". No caso brasileiro, muito contribuiu para isso a regulamentação do divórcio em 1977, que permitiu aos cônjuges desfazer legalmente o vínculo matrimonial e constituir uma nova família, fato que acarretou mudanças substanciais no comportamento dos casais. Como resultado, podemos observar hoje, em nossa sociedade, a convivência de diferentes formas de relacionamentos afetivos, conjugalidade e família (Féres-Carneiro \& Ziviani, 2009).

Com essas questôes em mente, desenvolvemos um estudo para melhor entender uma forma de relacionamento amoroso atual a que estamos denominando "namorido". O termo, muito empregado na zona sul da cidade do Rio de Janeiro, refere-se a um tipo de relaçáo em que o casal, após um breve período de namoro, passa a morar junto, sem que a uniáo necessariamente seja ou venha a ser formalizada. Diferentemente da coabitaçáo tradicional, forma antiga de conjugalidade, aos poucos um vai ficando cada vez mais na casa do outro até que resolvem compartilhar suas vidas. Acreditamos que este curto período de tempo entre o namoro e a coabitaçáo espelha a velocidade e a urgência com que tudo acontece no mundo contemporâneo. Como apontam Bauman (2004) e Badinter (1986), o desejo hoje é satisfeito o quanto antes. Não há mais tempo para cultivá-lo, pois retardar a satisfação é sinônimo de sacrifício. É nosso ponto de vista que esta rápida decisão de viver junto compartilha esta lógica.

O período de coabitação do "namorido" pode se estender, transformandose em uma uniáo estável, que pode nunca vir a ser oficializada numa cerimônia religiosa ou civil. Ela pode, contudo, chegar a ser formalizada, de alguma forma, após um período de convivência ou mesmo após o nascimento de filhos. Por fim, o "namorido" pode ser visto também como o que poderíamos denominar de um período de test drive para que os parceiros se conheçam melhor antes de optar 
por uma união mais definitiva, seja ela formalizada ou não. O que importa não é planejar previamente o desfecho do "namorido", mas sim ter a flexibilidade para poder decidir livremente se e como as pessoas envolvidas desejam alterar o status da relação. Diferentemente do passado, em que a união amorosa, como assinalamos antes, pertencia aos interesses familiares, hoje ela pertence aos desejos dos indivíduos. Portanto, oficializar o relacionamento para a sociedade, para a religiáo ou para o Estado não tem maior importância para os parceiros.

Uma das vantagens da coabitação é a eliminação da papelada em caso de rompimento. Como aponta Greenwald (1970), o casamento dificulta o processo de separação, transformando-o em uma burocracia "nonsense". Se a "cola" que une as pessoas é a livre escolha de permanecer junto, a insatisfação do casal deveria ser suficiente para eles se separarem. Assim, para Greenwald (1970: 55), "If state registration were eliminated, people would stay together for the only reason that makes marriage really viable - because they wanted to". Além disso, como assinala Prost (1992), devido à crença na impossibilidade de "amar por contrato", muitas pessoas hoje temem que a oficialização do relacionamento seja sua destruição, uma vez que o afeto corre o risco de passar a ser obrigatório e não espontâneo.

Para Jablonski (1991), o casamento apresenta algumas desvantagens, como a perda da liberdade, o surgimento da rotina, da monotonia, o aumento dos deveres e responsabilidades, entre outras. Porém a essas desvantagens são contrapostos benefícios, como a segurança emocional, a possibilidade de ter filhos em condiçóes ideais, uma sexualidade mais ativa e legitimada, entre outros. Para Prost (1992), a falta de compromisso oficial pode permitir, inclusive, uma melhor qualidade da relaçáo, uma vez que a possibilidade de rompimento a qualquer momento levaria o casal a investir mais constantemente no relacionamento.

No "namorido", há uma ausência de formalização social, pelo menos inicialmente. Isto não desmerece a união, uma vez que alguns amigos e parentes a reconhecem, ainda que nem sempre os parentes e, por vezes, até mesmo os pais sejam comunicados ou conheçam os companheiros de seus filhos. Também na Europa, como assinala Prost (1992), segundo estatísticas de 1977, 25\% das famílias atuais não são comunicadas sobre o fato de um de seus descendentes estar vivendo uma relação de coabitação. Como aponta Badinter (1986), mesmo no caso dos casais que vão formalizar uma união, não há mais uma preocupação com a criação de laços entre as famílias. Muitas vezes, os parentes só vão se conhecer no dia da celebraçáo do casamento. Diferentemente do passado, quando o casamento fazia parte dos interesses familiares, hoje ele se restringe ao desejo dos indivíduos. Isso se dá, segundo Giddens (2002: 19), porque o compromisso agora é com a relação em

Psic. Clin., Rio de JANeiro, vol.23, N.2, P.II7 - I35, $201 \mathrm{I}$ 
si e as "oportunidades de intimidade e de autoexpressão", algo que estava ausente em muitos "contextos mais tradicionais".

Finalmente, vale ressaltar que, em nenhum momento, foi afirmado aqui que o surgimento de um tipo de relacionamento amoroso significa o desaparecimento de outro(s). Como vêm apontando Vaitsman (1994) e Féres-Carneiro e Ziviani (2009), entre outros autores, diferentes formas de relacionamento amoroso coexistem atualmente. Dependendo do contexto, uma se sobressai à outra. Isso porque, como afirma Hall (2006), valores antigos não deixam de existir apenas pelo fato de surgirem novos modelos e, assim, segundo o autor, padróes antigos e modernos de relacionamentos afetivos podem coexistir durante algum tempo e, dependendo das escolhas pessoais e do momento, uns ficam mais evidentes que outros.

\section{MÉTOdo - Estudo de CAMPo}

Para melhor investigar o "namorido", forma de relacionamento cada vez mais comum entre jovens de classe média da zona sul da cidade do Rio de Janeiro, foram entrevistadas cinco mulheres envolvidas neste tipo de relaçáo, com idades entre vinte e sete e trinta e sete anos ${ }^{3}$. Todas elas trabalham fora de casa, moram junto com o companheiro, compartilham as responsabilidades pela casa e estão envolvidas, há pelo menos um ano, neste tipo de relacionamento amoroso. As entrevistadas seráo identificadas como P1, P2, P3, P4 e P5. As entrevistas foram semidirigidas, isto é, seguiram um roteiro previamente estruturado, foram gravadas em áudio com a permissão das entrevistadas, que assinaram um Termo de Consentimento Livre e Esclarecido, e foram transcritas na íntegra. Os textos resultantes das transcriçóes foram submetidos a uma análise de discurso a partir das seguintes categorias: Início da relação afetiva e coabitação; Oficialização do relacionamento; "Namorido" e casamento; Divisão de tarefas e responsabilidades.

\section{ANÁLISE E discussão dos Resultados}

\section{Início da relação afetiva e coabitação}

Todas as entrevistadas iniciaram o namoro pouco tempo depois de conhecer seu atual cônjuge em situaçóes que variaram do ambiente de trabalho a academias de ginástica ou dança e a sites de relacionamento. Do namoro à coabitaçáo o processo foi rápido, ainda que gradual, isto é, um deles ia dormindo na residência do outro, ficando cada vez mais tempo, até decidirem dividir o mesmo teto. $\mathrm{Ou}$ 
seja, o "foi ficando" iniciou-se junto com o namoro, com exceção da entrevistada P3, que morava com os pais: "E aí foi chegando a tralha dele, eu abri um espaço no armário, foi chegando a tralha dele" (P5).

O período de tempo decorrido entre o início do namoro e o casal decidir morar junto girou em torno de 5 meses. Apesar disso, a maioria das entrevistadas sentiu esse processo de transição entre o namoro e a decisão de coabitação como um período demorado. Tal fato pode ser reflexo da ansiedade gerada pela fluidez e transitoriedade do momento atual, como apontado por autores como Bauman (2004), para quem, como assinalamos antes, a sociedade contemporânea é movida pelo consumo, pelo impulso imediatista e a satisfação instantânea dos desejos, pois retardá-la é sinônimo de sacrifício. Essa impaciência elimina o período de tempo necessário para o "investimento no cultivo do desejo" (Bauman, 2004: 26), que deve ser saciado imediatamente.

Apesar de todas as entrevistadas se referirem ao companheiro como marido, no início era difícil para os membros do casal definir o tipo de relacionamento que estavam vivenciando. Uma vez que a união não teve uma celebração religiosa ou cerimônia civil, como acontece nos casamentos oficializados, eles não se consideravam casados. Atualmente, contudo, por falta de um termo melhor, afirmaram se referir a seus companheiros como marido, esposo, parceiro ou companheiro: "Como é que eu ia falar, né? [...] Eu sempre apresentei ele como parceiro [...] já cheguei depois de algum tempo a falar marido [...] Mas realmente sinto falta de um termo que poderia ser namorido, né?" (P1).

Apesar disso, consideram-se "casadas", mesmo afirmando que seu relacionamento não é como um casamento tradicional. $\mathrm{O}$ companheiro é visto como um namorado, ou seja, alguém de quem gostam, sem, contudo, haver nenhuma garantia de que a relaçáo vá se tornar um casamento. Ao mesmo tempo, ele também pode ser considerado um marido, isto é, alguém com quem dividem os planos de uma vida em comum, a residência, as despesas e os cuidados com a casa, daí a denominação "namorido", uma junção de namorado e marido. Este tipo de relacionamento vivido pelas entrevistadas é coerente com o que Giddens (1993) denominou relaçôes puras contemporâneas, ou com os chamados amores líquidos a que se refere Bauman (2004).

Apesar de o início da relação ter sido movido pelo desejo, podemos dizer que, em parte, a coabitaçáo foi impulsionada, segundo a maioria das entrevistadas, pela questão financeira, uma vez que as despesas individuais passaram a ser compartilhadas:

Eu falei [...] "a gente tem que decidir porque financeiramente não está sendo bom pra mim. Eu praticamente moro com você. Eu tenho um apartamento 
lá, eu tenho que resolver isso. Entáo o que a gente decide? A gente vai morar junto?” [...] Aí a gente decidiu que eu ia morar com ele. Aí eu fiz a rescisão do contrato (P1).

Como aponta Jablonski (1991), as unióes não são pautadas exclusivamente no afeto, mas, antes, outras questôes também são levadas em consideração no momento em que se decide compartilhar a vida com alguém. O custo de se manter dois apartamentos quando o que se quer é estar ao lado da pessoa desejada pode ser considerado um fator de peso na decisão de morar junto.

\section{Oficialização do relacionamento}

Com relação à oficialização formal da relação, como aponta Badinter (1986), a união passou a ser algo da esfera do privado, que diz respeito apenas ao casal e não mais à família ou à sociedade. Com a importância atribuída à satisfação pessoal, é o casal que decide os rumos da relação. Assim, para quase todas as entrevistadas houve apenas uma formalização da união entre o casal, geralmente marcada pela troca de alianças:

Um ano que a gente tava morando junto [...] e ele disse "Seu presente não vai vir agora porque tenho que mandar fazer". Eu não desconfiava que era uma aliança assim, porque ele num gosta dessas coisas, desse romantismo e tal que mulher gosta [...]. Aí ele deixou as alianças no meu armário, deixou um bilhetinho e perguntou se eu queria casar com ele. [...] Aí falei assim "Ué, mas eu já sou casada!” [...] "eu já sou casada com você” [...] Aí ele foi lá, pegou, tirou e desde entấo que a gente usa (P3).

O ritual de troca de alianças, do qual somente o casal participou, marcou, de certa forma, a consolidação de uma união mais séria. Ela pode ser vista aqui como uma atitude simbólica de que a relaçáo deve perdurar, pelo menos durante algum tempo, de modo que vale a pena investir nela. Para Giddens (1993) e Bauman (2004), as relaçôes consumadas por um breve período não trazem um sentimento de segurança, porque não possibilitam às pessoas envolvidas o tempo necessário para o desenvolvimento de aspectos importantes, como a intimidade e a cumplicidade, para a sensação de segurança de uma relaçáo. Diante da fluidez das sociedades contemporâneas, a demonstraçáo de algum tipo de compromisso com a relação, como esta troca de alianças, é fundamental para estabilizar o vínculo entre o casal. Assim, essa formalizaçáo não oficial foi descrita pelas entrevistadas como um momento especial e significativo do relacionamento do casal, uma demonstração de que ele é sério e duradouro. 
Apesar de o casal ter sentido, em determinado momento, necessidade de validar a união entre eles, nossas entrevistadas se mostraram desfavoráveis às formas tradicionais de oficialização da relação, percebidas pela maioria delas como um grande teatro: "Eu não me vejo, eu não vou casar, eu não consigo, não consigo me imaginar naquele vestido, naquele teatro" (P4).

Para Giddens (1993), o importante no relacionamento amoroso atual é o comprometimento com a própria relaçáo. Talvez por isso, para as entrevistadas, oficializar o relacionamento, quer através do casamento civil ou religioso, soe falso, pareça um grande teatro.

A forte participação da família na vida do casal, outrora existente, parece ter desaparecido. Assim, não houve nenhuma apresentação formal das famílias. Para a maioria das entrevistadas as pessoas foram se conhecendo aos poucos, com o passar do tempo. Esta situação vai ao encontro da afirmação de Badinter (1986) de que as famílias hoje não conhecem, muitas vezes, os parceiros dos filhos e, muito menos, suas respectivas famílias.

\section{3. "Namorido" e casamento}

Para as entrevistadas, no casamento oficial entraria em cena um jogo de interesses, sem uma preocupação maior dos cônjuges em cuidar do relacionamento, uma vez que a dissolução desse laço é difícil, seja pela burocracia envolvida no processo de separação, seja porque, mesmo não estando satisfeitos, os cônjuges podem, muitas vezes, continuar casados apenas para manter as aparências ou por uma questáo de acomodaçáo. Além disso, segundo elas, no casamento tradicional, ainda se espera que as pessoas cumpram papéis pré-determinados, como o do homem provedor e da mulher responsável pelos cuidados da casa e da saúde e educação dos filhos.

O casamento da irmã dele é um processo muito de dominação, de mulher subserviente e do marido, assim, de determinação. [...] como se tivesse uma amarra ali [...] algumas coisas não são tomados cuidados porque "Ah, é casada mesmo". Como se náo fosse se dissolver, pudesse fazer o que quiser (P4).

Às vezes a pessoa é casada porque ela sente uma pressão, a família pressionou. Tem muito caso de mulher que casa só pra não ficar solteira [...] ou acaba se acomodando naquele relacionamento (P1).

Parece, assim, que o matrimônio oficial ainda é percebido pelas entrevistadas nos moldes tradicionais, ou seja, como um tipo de relação marcada por uma divisão de papéis segundo o sexo, como se o casamento contemporâneo não tivesse sofrido 
mudanças ao longo do tempo. Há, contudo, para elas, uma distinção entre o casamento oficial e um relacionamento de coabitação como o "namorido". Este último teria como vantagem sobre o casamento tradicional o fato de não ser oficializado e, assim, poder ser mais facilmente dissolvido, o que faz com que o casal tenha um maior comprometimento e cuidado com a relação para que ela se mantenha:

Do ponto de vista do relacionamento em si eu acho até que a pessoa que náo é casada ela tem um comprometimento maior, porque ela tá ali porque ela quer (P1).

Acho que o fato de não ter nenhum documento assinado é... deixa o outro mais cuidadoso $[\ldots]$ tem um cuidado maior com o relacionamento (P4).

Outra vantagem do "namorido" em relação ao casamento, segundo as entrevistadas, é não ter que dar satisfação de seus atos para a família, como geralmente acontece com as pessoas casadas. Para elas, uma vez que a aprovação dos pais não foi solicitada quando resolveram morar juntos e os pais não são participados das atitudes e decisóes dos cônjuges, não se intrometem na vida do casal: "Acho que tem menos cobrança, acho que você se rende menos a pressóes familiares, [...] acho mais prático também, porque quando você se casa, casa com a família do outro e quando você se junta, [...] a gente resolve realmente entre a gente" (P2).

Em parte, isto se deve ao fato de que, como o casal não assumiu nenhum compromisso diante da família, do Estado ou da religião, também não necessita compartilhar o que acontece na sua relação conjugal com essas instituiçóes, como, por exemplo, comunicar a união ou a separação, quando ela ocorre. Esta questão levantada pelas entrevistadas vai ao encontro dos dados apresentados por Prost (1992), de que $25 \%$ das famílias não são comunicadas sobre o fato de que um de seus descendentes está vivendo uma relação de coabitação.

A questão financeira surge aí quando comparam o "namorido" com o casamento. Além de morar junto com alguém ser vantajoso porque se podem dividir as despesas, também é mais econômico do que casar, uma vez que não há gastos com uma cerimônia de casamento: "O dinheiro que você empregaria numa festa você investiria muito em um apartamento que você alugar ou você até poderia dar entrada" (P3).

Como náo é necessário passar por nenhum processo burocrático, a facilidade de se separar também é considerada uma vantagem do "namorido" sobre o casamento, uma vez que tudo se dá de forma bem mais rápida:

Eu sei que ele tá totalmente livre. Se ele se envolver com alguém, ele pode amanhă falar "Ó, tô indo". Eu sei que não tem nada que me amarra a ele [...] 
Os dois estão livres. Eu fico imaginando assim, caramba, se tá tudo amarrado, vai ter que entrar com advogado, tem que entrar com aquilo, né? É muito mais amarra (P4).

$\mathrm{Na}$ hora que eu quiser sair, eu quero sair, eu quero ter a liberdade de sair sem ter que passar por nenhuma burocracia (P5).

Esta facilidade de sair de um relacionamento amoroso não oficializado vai ao encontro do que é apontado por Giddens (2002) e Bauman (2004), para quem, nas relaçóes puras ou fluidas contemporâneas, quando o envolvimento afetivo deixa de ser satisfatório para um dos membros do casal, cada um vai para o seu canto. Além disso, como afirma Greenwald (1970: 54), uma das vantagens da união não legalizada é justamente "the elimination of the nonsense of most divorce proceeding".

Acresce-se a isso o fato de que, como afirmaram nossas entrevistadas, uma relação não oficializada não faz com que a união entre os cônjuges seja menos comprometida, uma vez que elas acreditam que não é a assinatura de um papel que define o vínculo entre duas pessoas: "Eu acho que esse vínculo de relacionamento ele independe do casamento, independe se tem papel passado ou não. Então eu vejo assim, o vínculo que eu tenho com o PI é muito forte, muito grande, então eu não vejo que tenha, assim, uma diferença no relacionamento por causa disso" (P1).

A visão das entrevistadas de que não ter garantias externas que protejam a união não faz com que ela seja vista como menos comprometida vai ao encontro da ideia defendida por Giddens (2002: 14) de que, na contemporaneidade, a confiança na relação "não pode mais ancorar-se por definição em critérios externos à própria relação - como os critérios de parentesco, dever social ou obrigação tradicional", mas, antes, o compromisso deve ser com o(a) companheiro(a) e com a relação.

Apesar disso, segundo algumas entrevistadas, o casamento oficializado traz algumas vantagens. Duas delas mencionaram certos entraves de cunho burocrático quando não se é oficialmente casado, como é o caso, por exemplo, da impossibilidade de elas serem incluídas como dependentes no plano de saúde do companheiro: "Facilita também você casar porque [...] se você não tem um vínculo com a outra pessoa, dificulta, sabe? Tipo plano de saúde, eu quero ser dependente dele e não consegui" (P3).

4. Divisão de tarefas e responsabilidades

Para todas as entrevistadas, a divisão das despesas não foi combinada com o companheiro, mas, antes, foi acontecendo naturalmente com o desenrolar da

Psic. Clin., Rio de JANeiro, vol.23, N.2, P.II7 - I35, $201 \mathrm{I}$ 
relação. Em alguns casos, elas eram inicialmente as principais provedoras e, em outros, eram eles que assumiam a maior parte dos gastos. Atualmente, contudo, há, segundo elas, uma divisão mais clara sobre quem arca com que tipo de despesa dentro de casa. A maioria das entrevistadas relatou que há um certo equilíbrio entre os membros do casal nesta divisão de despesas com o companheiro.

No começo o MP1 assumiu todas as contas. Não foi conversado... foi acontecendo... (P1).

Ele pagava algumas contas, ele pagava outras ou... como ele tava na minha casa eu pagava tudo e a gente só foi dividir o negócio só mais à frente, porque eu pagava as contas, mas em compensaçáo foi ele quem comprou o freezer e foi ele quem comprou num sei mais quê (P5).

Se a divisão financeira não foi acordada, mas, ao contrário, foi se dando naturalmente ao longo do tempo, a divisão das tarefas domésticas, ao contrário, foi combinada logo no início do relacionamento: "Sim, isso a gente combinou, isso a gente combinou de cara" (P1).

A impressão que se tem é que, se houvesse um contrato escrito entre o casal, esta questão constituiria uma de suas cláusulas. Em alguns casos, o estabelecimento de normas com relaçáo a quem faz o quê partiu dos homens e, em outros, das mulheres. Percebemos, contudo, que a maioria das mulheres, como acontece nos casamentos tradicionais, ficou responsável pelo trabalho doméstico e por gerenciar o trabalho da empregada. Quase todas elas, no entanto, afirmaram dividir algumas funçóes com o parceiro, ainda que a maior parte das tarefas caiba a elas:

Bom, vou te dar o exemplo de lavar louça, é o que eu mais detesto. Então a gente tinha montado uma tabelinha, um pauzinho pra mim quando eu lavo a louça, um pauzinho para ele [...] E quem tinha mais pauzinhos poderia escolher quem lavaria a louça. O problema é que eu ganhei pauzinhos desesperadamente e chegou em um ponto que eu falei o seguinte: "Eu não lavo mais louça". E a louça foi ficando, foi ficando, [...]. Ele sugeriu que a gente comprasse talheres e pratos descartáveis ( $\mathrm{P} 5)$.

Suas afirmaçóes vão ao encontro do que é assinalado por Jablonski (2007), para quem os homens ajudam, mas náo tomam para si a responsabilidade. A exceçấo à regra ficou por conta de duas entrevistadas, P1 e P4. A primeira vive um relacionamento nos moldes tradicionais, com uma distribuiçâo tradicional das tarefas de casa, em que ela se responsabiliza por todo trabalho doméstico, algo que foi acordado entre eles desde o início da relação. No outro extremo encontramos 
P4, que é quem gerencia o dinheiro do casal, enquanto que a seu companheiro cabe administrar as tarefas domésticas, cobrando, inclusive dela, que faça a sua parte, ou seja, que contribua para a organização do lar.

\section{Conclusóes}

Nossos resultados vão ao encontro do que tem sido assinalado por diversos estudiosos atuais, como Giddens (2002) e Bauman (2004). Para eles, nas sociedades contemporâneas, a exacerbação do individualismo moderno favoreceu o surgimento de novas formas de conjugalidade. Se outrora o desejo individual dos cônjuges bem como seu papel no casamento eram externamente referidos e tinham que ser sacrificados em nome de interesses e normas familiares e sociais, hoje, como aponta Giddens (2002: 87), "o casamento se torna mais e mais uma relação iniciada pela satisfação emocional que deriva do contato próximo com o outro, e enquanto essa satisfação persistir ele se mantém". Ou seja, na contemporaneidade, a aprovação dos pais e a existência de filhos, entre outras questóes, deixaram de constituir aspectos importantes para a manutenção de um casamento e o fundamental para os indivíduos passou a ser o seu próprio prazer pessoal. Hoje, quando um envolvimento amoroso traz satisfação, independentemente de ser um casamento oficializado ou não, a pessoa permanece na relação. Caso contrário, para usar a expressão empregada pelos jovens cariocas, "a fila anda".

Pelo que pudemos observar na fala de nossas entrevistadas, o "namorido" está muito próximo do que Giddens (1993) chama relaçôes puras, ou do que Bauman (2004) denomina relacionamentos fluidos. No "namorido", como nas relaçóes puras ou fluidas a que se referem os autores, a união acontece por vontade própria do casal, a coabitação é precedida por um curto período de namoro, há uma realizaçáo rápida do desejo de ficar junto e ela termina quando a relação não traz mais satisfação para as pessoas nela envolvidas. Ou seja, os "namoridos" dispensam um tempo maior para o conhecimento mútuo, já que a coabitação vai acontecendo pouco a pouco e não há compromisso com a sua durabilidade, bem como com a oficializaçáo da relaçáo, mas apenas com a satisfação dela extraída.

O "namorido" se mostra um relacionamento aparentemente flexível e seu funcionamento não segue necessariamente a divisão tradicional dos papéis de gênero. $\mathrm{O}$ importante é que os acordos efetuados entre o casal sejam agradáveis e satisfatórios para ambos. Então, se uma divisão mais igualitária das tarefas domésticas vai ou não ocorrer, e se o relacionamento será ou não oficializado no futuro, não são questôes fixas, pré-estabelecidas e importantes no "namorido", mas, antes,

Psic. Clin., Rio de JANeiro, vol.23, N.2, P.II7 - I35, $201 \mathrm{I}$ 
são acordadas e podem se alterar ao longo do tempo. Por outro lado, não podemos deixar de assinalar aqui que, de modo geral, a despeito das mudanças no plano do discurso, a mulher permanece responsável pelos cuidados da casa, ainda que as despesas financeiras sejam, no caso de nossas entrevistadas, divididas. De qualquer modo, o mais importante no "namorido" é a satisfação das pessoas nele envolvidas e, como também ocorre nos casamentos atuais, não há um compromisso com a eternidade da relação como acontecia nos casamentos tradicionais. No "namorido" os cônjuges se comprometem apenas com a qualidade da relação. E, como não há uma oficialização da relação, não parece ser necessário que o casal dê satisfaçóes a familiares ou à sociedade sobre o seu relacionamento amoroso.

Como pudemos também observar na fala das entrevistadas, uma das vantagens do "namorido" reside no fato de que, como esta é uma união sem burocracias ou formalidades, pode ser mais facilmente desfeita quando deixa de ser satisfatória para um de seus membros. Deste modo, haveria um maior investimento dos cônjuges na relação, uma maior dedicação aos parceiros e maior preocupaçáo com a manutenção da qualidade da relação para evitar a insatisfação do outro, diferentemente do que ocorre no casamento, em que o compromisso oficializado pode levar a uma acomodaçáo do casal à situaçáo, independente de ela ser satisfatória ou náo.

Pelo menos em um primeiro momento, não há nenhum compromisso com a oficialização e a celebraçáo da união, o que dispensa o tempo e o dinheiro necessários para se ocupar dessas questóes e, muitas vezes, as famílias do casal não são nem ao menos comunicadas da decisão do casal. Do mesmo modo, não há nenhum compromisso no sentido da geração de descendentes. Também não se faz necessário um período para montar a residência do casal, uma vez que, geralmente, um dos parceiros se muda para a residência do outro; mesmo que o casal inicie a coabitaçáo em um terceiro local, ambos levam seus pertences e, caso falte alguma coisa, compram ou ganham de familiares e amigos.

Para finalizar, gostaríamos de assinalar que, se o "namorido" é uma nova forma de conjugalidade ou apenas algo próprio das camadas médias intelectualizadas da zona sul da cidade do Rio de Janeiro, preferimos deixar em aberto para ser melhor explorado em futuros trabalhos. Futuramente, pretendemos saber também como os homens envolvidos em uma relaçáo de "namorido" percebem este tipo de relacionamento. Por ora, cabe concluir assinalando que a fluidez e a agilidade, tanto na união quanto na possível dissolução da relação encontrada no "namorido", sáo condizentes com a transitoriedade dos tempos atuais. Sua praticidade e sua flexibilidade parecem ser, assim, bastante sedutoras. 


\section{REFERÊNCIAS}

Badinter, E. (1986). Um é o outro: relaçôes entre homens e mulheres. (Trad. C. Gomes). Rio de Janeiro: Nova Fronteira.

Bauman, Z. (2004). Amor líquido: sobre a fragilidade dos laços humanos. (Trad. C. A. Medeiros). Rio de Janeiro: Jorge Zahar.

Costa, J. F. (1989). Ordem médica e norma familiar. (3a. ed.). Rio de Janeiro: Ediçóes Graal.

Del Priore, M. D. (2006). História do amor no Brasil. (2a ed.). São Paulo: Contexto.

Féres-Carneiro, T., \& Ziviani, C. (2009). Conjugalidades contemporâneas: um estudo sobre os múltiplos arranjos amorosos na atualidade. In: Feres-Carneiro, T. (Org.). Casal e família: permanências e rupturas (pp. 83-109). São Paulo: Casa do Psicólogo.

Freyre, G. (1951). Sobrados e mucambos. (2a ed.). Rio de Janeiro: José Olympio Ed.

Giddens, A. (1993). A transformação da intimidade: sexualidade, amor e erotismo nas sociedades modernas. (Trad. M. Lopes). São Paulo: UNESP.

Giddens, A. (2002) Modernidade e identidade. (Trad. P. Dentzien). Rio de Janeiro: Jorge Zahar.

Greenwald, H. (1970). Marriage as a non-legal voluntary association. In: Otto, H. A. (Org.). The family in search of a future: alternate models for moderns (pp. 51-56). New York: Meredith Corporation.

Hall, S. (2006). A identidade cultural na pós-modernidade. (11 a ed.). (Trad. T. T. Silva e G. L. Louro). Rio de Janeiro: DP\&A.

Jablonski, B. (1991). Até que a vida nos separe: a crise do casamento contemporâneo. Rio de Janeiro: Agir.

Jablonski, B. (2007). O cotidiano do casamento contemporâneo: a difícil e conflitiva divisão de tarefas e responsabilidades entre homens e mulheres. In: Féres-Carneiro, T. (Org.). Família e casal: saúde, trabalho e modos de vinculação (pp. 203-228). São Paulo: Casa do Psicólogo.

Mello, E. C. (1997). O fim das casas grandes. In: Alencastro, L. F. (Org.). História da vida privada no Brasil: império: a corte e a modernidade nacional (v. II, pp. 385-437). São Paulo: Companhia das Letras.

Prost, A. (1992). Fronteiras e espaços do privado. In: Ariès, P. e Duby, G. (Orgs.). História da vida privada: da primeira guerra a nossos dias (v. V, pp. 13-153). (Trad. D. Bottmann). São Paulo: Companhia das Letras.

Vaitsman, J. (1994). Flexiveis e plurais: identidade, casamento e família em circunstâncias pós-modernas. Rio de Janeiro: Rocco.

Psic. Clin., Rio De JANeiro, vol.23, N.2, P.II7 - I35, $201 \mathrm{I}$ 


\section{Notas}

1 O termo "namorido" é usualmente empregado por mulheres para se referir a este tipo de relacionamento, embora alguns homens atualmente já estejam começando a fazer uso dele para se referir à relação em que estão envolvidos. No que diz respeito ao parceiro, apenas as mulheres se referem a eles como meu "namorido". Em parte, isto pode ser explicado pelo fato de que os homens geralmente se referem a suas companheiras, inclusive esposas e namoradas, como minha "mulher", diferentemente das mulheres, uma vez que não é socialmente aceito que uma mulher se refira a seu companheiro como meu "homem", termo considerado impróprio para uso por "mulheres de bem".

2 Ao falar de casamento tradicional, faço referência ao casamento oficializado no civil e/ou religioso que funciona de acordo com o modelo de gênero no qual a mulher fica em casa cuidando da educação dos filhos e o homem é o provedor financeiro da família. Ou, ainda, mesmo que a mulher trabalhe, ela continua sendo a principal responsável pelo gerenciamento da casa e pela maior parte dos afazeres domésticos. Esse modelo foi construído a partir de um discurso social e atende às necessidades de um determinado momento histórico. Assim, o casamento tradicional, além dos ritos seculares de oficialização, também está impregnado da divisão de papéis por gênero. Seu retrato ideal é o da família composta pelos cônjuges, um homem e uma mulher, e um ou dois filhos, de preferência uma menina e um menino.

3 Optamos por entrevistar inicialmente 5 mulheres. O número limitado de participantes devese ao fato de que estamos fazendo uso de entrevistas aprofundadas que serão submetidas a uma análise de discurso, metodologia em que, se, por um lado, se pode aprofundar mais os temas tratados, por outro, o número de participantes é mais reduzido. Posteriormente, pretendemos, não apenas entrevistar mais mulheres, a fim de reforçarmos ou não os resultados encontrados, como também entrevistar homens, com o objetivo de entender como eles veem este tipo de relação, como consta do nosso projeto inicial.

Recebido em 25 de abril de 2011 Aceito para publicação em 8 de agosto de 2011 